\title{
NGNP Engineering Status
}

\author{
August 2010
}

The INL is a

U.S. Department of Energy National Laboratory

operated by

Battelle Energy Alliance

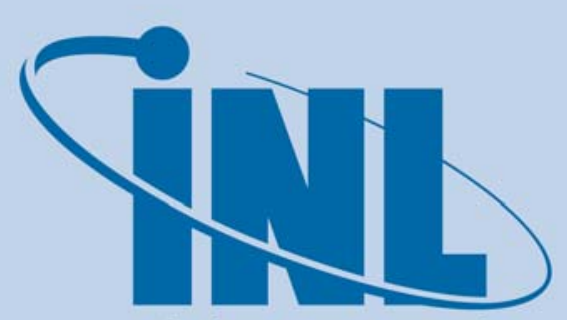

Idaho National Laboratory

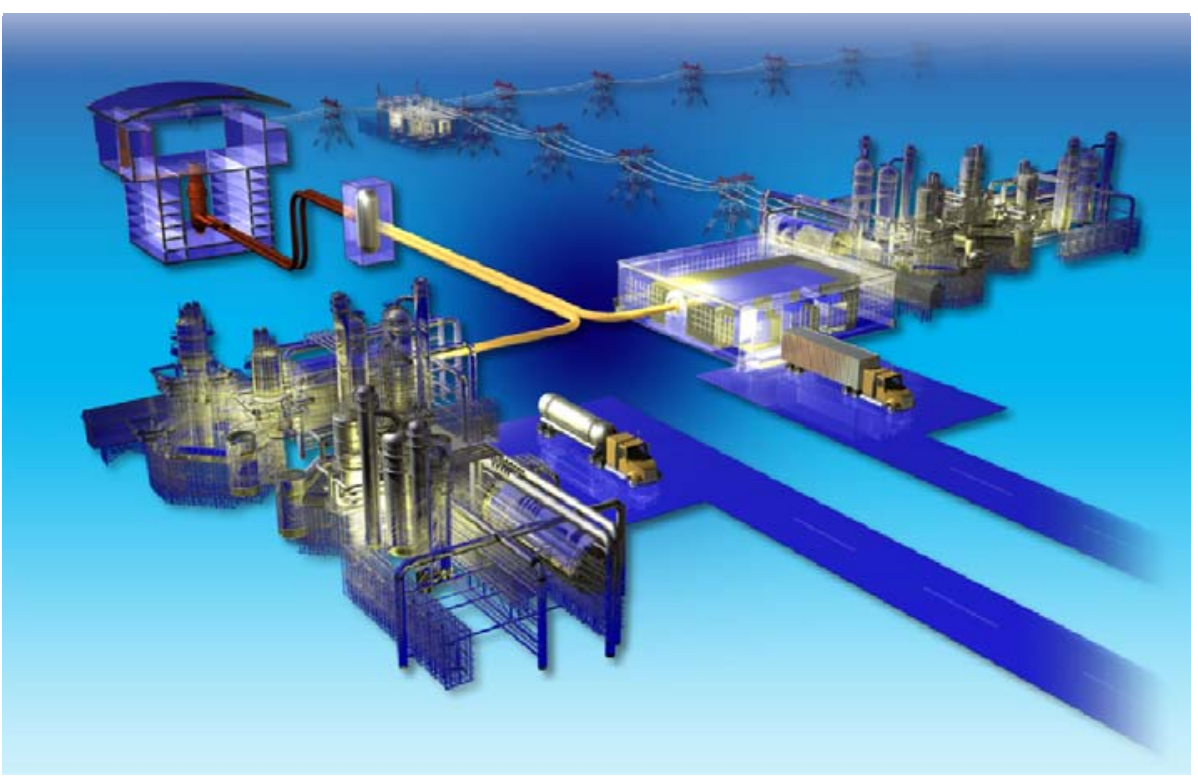




\section{DISCLAIMER}

This information was prepared as an account of work sponsored by an agency of the U.S. Government. Neither the U.S. Government nor any agency thereof, nor any of their employees, makes any warranty, expressed or implied, or assumes any legal liability or responsibility for the accuracy, completeness, or usefulness, of any information, apparatus, product, or process disclosed, or represents that its use would not infringe privately owned rights. References herein to any specific commercial product, process, or service by trade name, trade mark, manufacturer, or otherwise, does not necessarily constitute or imply its endorsement, recommendation, or favoring by the U.S. Government or any agency thereof. The views and opinions of authors expressed herein do not necessarily state or reflect those of the U.S. Government or any agency thereof. 


\section{NGNP Engineering Status}

August 2010

\section{Idaho National Laboratory \\ Next Generation Nuclear Plant Project Idaho Falls, Idaho 83415}

Prepared for the U.S. Department of Energy Office of Nuclear Energy Under DOE Idaho Operations Office Contract DE-AC07-05ID14517 


\section{Next Generation Nuclear Plant Project}

\section{Engineering Status}

INL/EXT-10-19261

August 2010

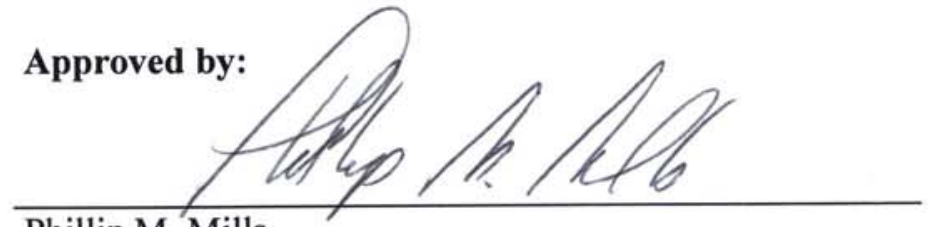

Phillip M. Mills

Engineering Director
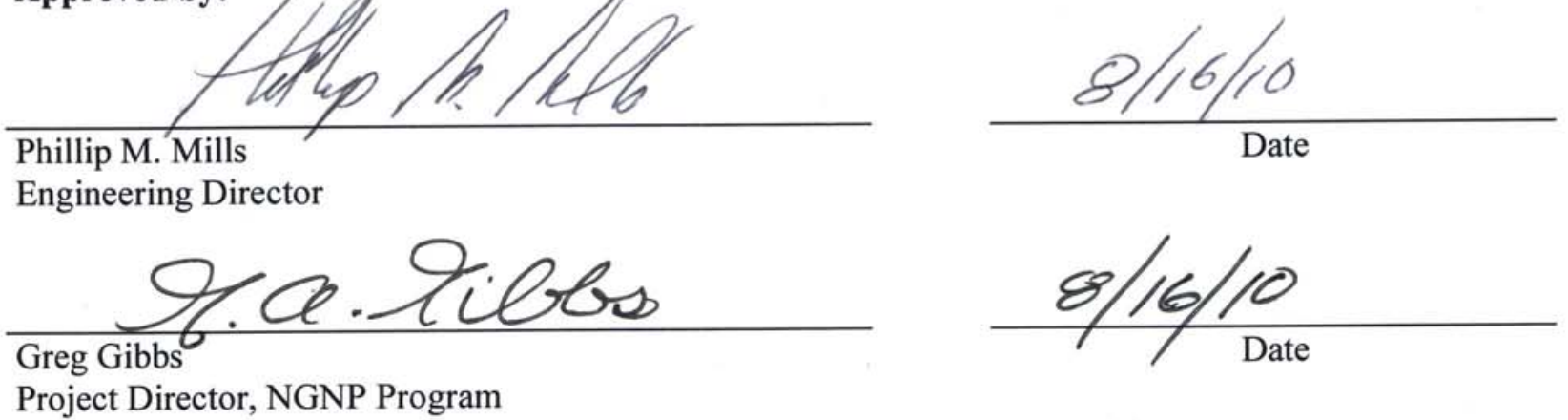


\begin{abstract}
The objective of this paper is to summarize the Engineering work that has been completed to date in support of the Next Generation Nuclear Plant (NGNP) Project. NGNP Project Engineering began with preconceptual design in fiscal year (FY) 2007 focused on the provisions of the Energy Policy Act of 2005 (EPAct). ${ }^{1}$ Subsequent to completion of the preconceptual design work, interactions with potential endusers in the Industrial Sector led to revisions in the functional, operational and siting requirements for NGNP from those applied in FY 2007. To support engineering development of NGNP and to satisfy these requirements several additional studies have been completed. These studies further developed specific design and operational requirements, developed and initiated implementation of technical risk reduction and management programs, including establishing programs to achieve the necessary technical readiness levels of developmental critical components, updated cost and schedule estimates for the NGNP and evaluated the technical and economic viability of specific applications of the technology in the industrial sector, and supported development of white papers used in preapplication licensing discussions with the U.S. Nuclear Regulatory Commission (NRC).
\end{abstract}




\section{CONTENTS}

ABSTRACT. viii

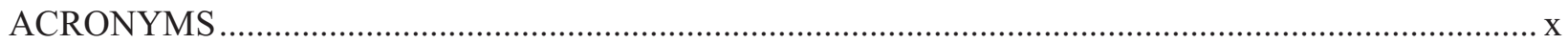

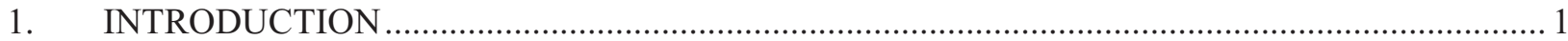

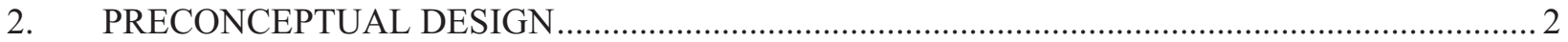

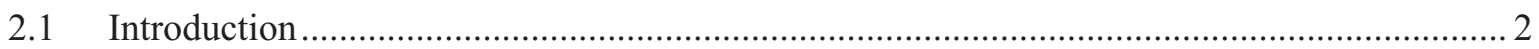

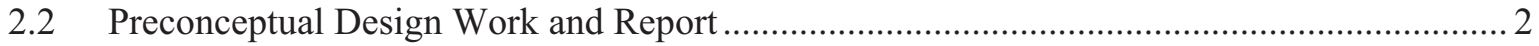

2.3 Preconceptual Design Team Recommendations ................................................................. 3

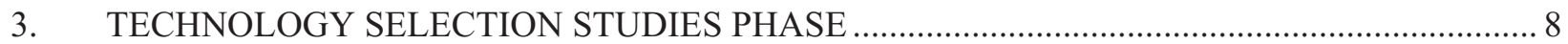

4. END-USER INPUT TO DEFINE SCOPE AND REQUIREMENTS …...................................... 10

4.1 Continuing Flexibility and Desire to Achieve Higher Operating Limits ............................ 10

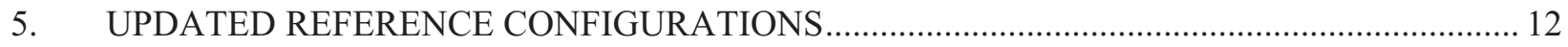

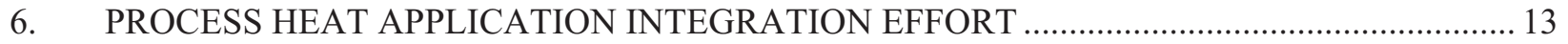

7. CODES, STANDARDS, AND DESIGN RULES DEVELOPMENT ........................................ 15

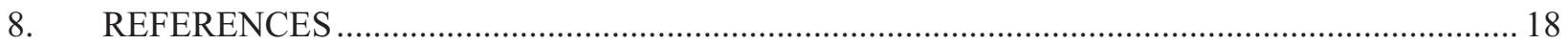

\section{TABLES}

Table 1. Summary of preconceptual-design-recommended operating conditions and plant

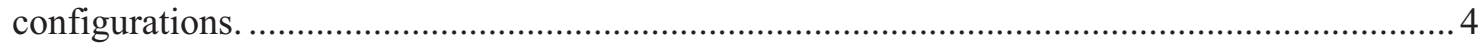

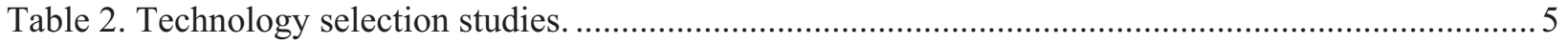

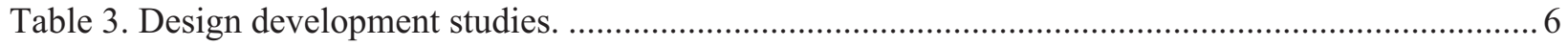

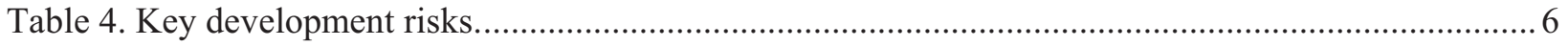

Table 5. Advancement of codes, standards and rules for the operation of high temperature gascooled reactors. 16 


\section{ACRONYMS}

\begin{tabular}{ll} 
ANS & American Nuclear Society \\
ASME & American Society of Mechanical Engineers \\
ASTM & American Society for Testing and Materials International \\
B\&PV & Boiler \& Pressure Vessel \\
DDN & design data need \\
DOE & U.S. Department of Energy \\
EPAct & Energy Policy Act of 2005 \\
FOA & Funding Opportunity Announcement \\
FOAK & first-of-a-kind \\
FY & fiscal year \\
GA & General Atomics \\
HTE & high temperature electrolysis \\
HTGR & high temperature gas-cooled reactor \\
HTSE & high temperature steam electrolysis \\
I\&C & instrumentation and controls \\
IAEA & International Atomic Energy Agency \\
IHX & intermediate heat exchanger \\
INL & Idaho National Laboratory \\
LWR & light water reactor \\
NGNP & Next Generation Nuclear Plant \\
NHI & Nuclear Hydrogen Initiative; also National Hydrogen Initiative \\
NHSS & nuclear heat supply systems \\
NRC & U.S. Nuclear Regulatory Commission \\
PCDR & preconceptual design reports \\
PCHE & printed circuit heat exchanger \\
PCS & power conversion system \\
R\&D & research and development \\
SAG & Senior Advisory Group \\
TDRM & Technology Development Roadmaps \\
TRL & Technology Readiness Levels \\
\hline
\end{tabular}




\section{Engineering Status}

\section{INTRODUCTION}

The objective of this paper is to summarize the Engineering work that has been completed to date in support of the Next Generation Nuclear Plant (NGNP) Project. NGNP Project Engineering began with preconceptual design in fiscal year (FY) 2007 focused on the provisions of the Energy Policy Act of 2005 (EPAct). ${ }^{1}$ Subsequent to completion of the preconceptual design work, interactions with potential endusers in the industrial sector led to revisions in the functional, operational and citing requirements for NGNP from those applied in FY 2007. To support engineering development of NGNP and to satisfy these requirements several additional studies have been completed. These studies further developed specific design and operational requirements, developed and initiated implementation of technical risk reduction and management programs, including establishing programs to achieve the necessary technical readiness levels of developmental critical components, updated cost and schedule estimates for the NGNP and evaluated the technical and economic viability of specific applications of the technology in the industrial sector, and supported development of white papers used in preapplication licensing discussions with the U.S. Nuclear Regulatory Commission (NRC). The key elements and conclusions of the preconceptual and subsequent design work are summarized in the following sections. 


\section{PRECONCEPTUAL DESIGN}

\subsection{Introduction}

The NGNP Project was initiated in 2006 at Idaho National Laboratory (INL) by the U.S. Department of Energy (DOE) as directed by the EPAct. The EPAct tasked the NGNP Project with demonstrating the production of hydrogen and/or electricity using high temperature gas-cooled reactor (HTGR) technology in a plant to be sited at the INL. Pursuant to this objective the NGNP Project issued a Request for Proposals for the development of a preconceptual design of HTGR plants for the production of electricity and hydrogen at the INL. The NGNP Project received and evaluated several proposals. Technically acceptable proposals were received and contracts were subsequently established to complete this work in FY 2007 with three teams headed by suppliers of HTGR technology. The Teams included the PebbleBed Technology Team (principally led by Westinghouse Electric Company, LLC, and PBMR Pty Ltd. from South Africa); AREVA NP, Inc.; and General Atomics (GA). These design teams were international in nature and each consisted of multiple team members providing specific capabilities relevant to HTGR development, nuclear power applications, and hydrogen production. A total of 26 companies participated in this design work.

In addition to the suppliers, the NGNP Project sought out and contracted with industry experts to provide independent reviews of both the suppliers' designs and the NGNP Project's approach. Several of these experts had previously participated in the Independent Technology Review Group which had reviewed design features and technology uncertainties for the NGNP. ${ }^{2}$

The preconceptual design work was completed by the three design supplier teams under the direction of NGNP Project Engineering in FY 2007. Each of the three teams and the NGNP Project prepared preconceptual design reports (PCDR) presenting the methods and conclusions of the work. ${ }^{3,4,5}$ The NGNP Project then developed a consolidated PCDR, which was submitted to DOE. ${ }^{6}$ The preconceptual design work had the objective of developing a framework in which the design and technology development of the NGNP could progress and to begin to develop bases for selection of the specific design and operational characteristics of NGNP. The scope of work included completion of special studies to address key aspects of the NGNP (e.g., reactor type, power levels, power conversion system (PCS) and heat transfer/transport system designs, licensing and end product disposition). The results of these special studies were applied to the development of a recommended design for NGNP and a commercial version of the HTGR by each contractor. These were then used to estimate costs and schedule for design; construction; licensing; startup and testing; operation; and deactivation, decontamination, and decommissioning of the NGNP and an economic assessment for an Nth of a kind commercial plant. A primary objective of this work was to identify research and development (R\&D) needs, design data needs (DDNs), and future studies required to support selection of key characteristics of and to support the design and licensing processes for the NGNP.

\subsection{Preconceptual Design Work and Report}

In the initial phase of the FY 2007 preconceptual design activities, the three contractor teams completed seven special studies to address key aspects of the NGNP design. The seven studies evaluated options for the reactor type (e.g., pebble bed versus prismatic block), power level, power conversion system type and ratings, heat transfer and transport system designs, primary and secondary cycle parameters, licensing and permitting, and by-product disposition. The results of these studies, combined with the provisions of the EPAct, provided the bases for selection of the configurations and operating conditions for the preconceptual designs developed by each contractor team.

The following summarizes the scope of these studies: 
- Reactor type: The Pebble-bed Technology Team selected the pebble bed reactor design while AREVA and GA selected the prismatic block reactor design for the NGNP.

- Power Level: It was recommended that the reactor prototype have the same power level as the commercial plant to minimize difficulty in translating safety, economic, licensing, costing, and operating experience from the prototype to the commercial plant.

- Heat Transfer and Transport: The results of these studies varied among the teams regarding secondary gas composition, reactor outlet temperature, heat transfer and transport configuration, heat exchanger design and materials, electrical power conversion system and the hydrogen production processes.

- Power Conversion Systems: The configurations of the power conversion systems evaluated included both direct Brayton cycle gas turbines, (e.g., turbines run on primary helium), indirect gas turbines, (gas turbines run on secondary gas heated through an intermediate heat exchanger) and Rankine steam turbine generators supplied from steam generators heated by secondary gas. The performance, flexibility and operability, technical readiness level, and technical risks (if additional development is required) were assessed for each alternative.

- Operating Parameters: Primary and secondary operating parameters, (e.g., reactor inlet and outlet temperature, helium pressures) and the basic configuration of the nuclear heat supply system were selected to be consistent with the NGNP mission, reactor design, power conversion system design, and prior gas-cooled reactor design development experience of each of the reactor supplier teams.

- Licensing and permitting: The special study on licensing and permitting made preliminary recommendations pertaining to the licensing approach, site and environmental permitting, design certification and the focus of research and development efforts.

- By-Products: This study identified, quantified, and described the disposition of end products and waste streams that would be generated by the prototype and the commercial plants. The studies identified the possible markets (both local and remote) for the electricity, hydrogen, and oxygen, as well as specific characteristics of the methods for treatment, transport and disposition of these products.

The NGNP Project judged that all of these variations had merit and should be carried through the preconceptual design phase of the NGNP Project by the three teams.

\subsection{Preconceptual Design Team Recommendations}

The key results of each contractor teams' evaluations and recommendations for the NGNP operating conditions and configuration were summarized in specific deliverables as described in Table 1. Recommendations were based on the state of the design work related to HTGR by each supplier and prior commercial applications of gas-cooled reactor technology. The reactor suppliers noted that achieving the recommended operating conditions requires significant design, licensing, and development effort. At that time an objective of the NGNP Project was to initiate the NGNP in the 2018 time frame. The Teams concluded that completing NGNP by 2018 requires balancing the selection of initial operating conditions and the plant configuration for NGNP against the schedule and cost risks associated with design, licensing, $\mathrm{R} \& \mathrm{D}$ and construction. This balance must also consider the impact of technology selections and operating conditions on the viability of translating the NGNP experience to private-sector applications. 
Table 1. Summary of preconceptual-design-recommended operating conditions and plant configurations.

\begin{tabular}{|c|c|c|c|}
\hline \multirow[b]{2}{*}{ Item } & \multicolumn{3}{|c|}{ Recommended Operating Conditions \& Plant Configuration } \\
\hline & Westinghouse & AREVA & General Atomics \\
\hline Power Level & 500 MWth & 565 MWth & $550-600 \mathrm{MWth}$ \\
\hline $\begin{array}{l}\text { Reactor Outlet } \\
\text { Temperature }\end{array}$ & $950^{\circ} \mathrm{C}$ & $900^{\circ} \mathrm{C}$ & $\mathrm{Up}$ to $950^{\circ} \mathrm{C}$ \\
\hline $\begin{array}{l}\text { Reactor Inlet } \\
\text { Temperature }\end{array}$ & $350^{\circ} \mathrm{C}$ & $500^{\circ} \mathrm{C}$ & $490^{\circ} \mathrm{C}$ \\
\hline Cycle Configuration & $\begin{array}{l}\text { Indirect-Series } \\
\text { hydrogen process and } \\
\text { power conversion }\end{array}$ & $\begin{array}{l}\text { Indirect-Parallel } \\
\text { hydrogen process and } \\
\text { power conversion }\end{array}$ & $\begin{array}{l}\text { Direct PCS } \\
\text { Parallel indirect hydrogen } \\
\text { process }\end{array}$ \\
\hline Secondary Fluid & $\mathrm{He}$ & $\begin{array}{l}\text { He-nitrogen to PCS } \\
\text { He to } \mathrm{H}_{2} \text { Process }\end{array}$ & $\mathrm{He}$ \\
\hline $\begin{array}{l}\text { Power Conversion } \\
\text { Power }\end{array}$ & $100 \%$ of reactor power & $100 \%$ of reactor power & $100 \%$ of Reactor Power \\
\hline $\begin{array}{l}\text { Hydrogen Plant } \\
\text { Power }\end{array}$ & $10 \%$ of reactor power & $10 \%$ of reactor power & $\begin{array}{l}5 \text { MWth-high temperature } \\
\text { electrolysis (HTE) } \\
60 \text { MWth-S-I }\end{array}$ \\
\hline Reactor Core Design & Pebble Bed & Prismatic & Prismatic \\
\hline Fuel & $\begin{array}{l}\text { TRISO } \mathrm{UO}_{2} 1^{\text {st }} \text { and } \\
\text { subsequent cores }\end{array}$ & $\begin{array}{l}\text { TRISO UCO }-1^{\text {st }} \text { and } \\
\text { subsequent cores }\end{array}$ & $\begin{array}{l}\text { TRISO } \mathrm{UO}_{2} 1^{\text {st }} \text { core } \\
\text { Variable subsequent cores }\end{array}$ \\
\hline Graphite & PCEA and NBG-18 & NGG-17 and NBG-18 & IG-110 \& NBG-18 \\
\hline $\begin{array}{l}\text { Reactor Pressure } \\
\text { Vessel Design }\end{array}$ & $\begin{array}{l}\text { Exposed to the gas inlet } \\
\text { temperature }\end{array}$ & $\begin{array}{l}\text { Exposed to the gas inlet } \\
\text { temperature; insulation } \\
\text { and vessel cooling options } \\
\text { may be pursued }\end{array}$ & $\begin{array}{l}\text { Exposed to the gas inlet } \\
\text { temperature }\end{array}$ \\
\hline $\begin{array}{l}\text { Reactor Pressure } \\
\text { Vessel Material }\end{array}$ & SA508/533 & $9 \mathrm{Cr}-1 \mathrm{Mo}$ & $\begin{array}{l}2-1 / 4 \mathrm{Cr}-1 \mathrm{Mo} \\
9 \mathrm{Cr}-1 \mathrm{Mo} \\
\end{array}$ \\
\hline $\begin{array}{l}\text { Intermediate Heat } \\
\text { Exchanger }\end{array}$ & $\begin{array}{l}\text { 2-Stage printed circuit } \\
\text { heat exchanger (PCHE), } \\
\text { In } 617 \text { material }\end{array}$ & $\begin{array}{l}\text { PCS-3-Helical Coil Shell } \\
\text { and Tube, In } 617 \\
\text { Process-PCHE or Fin- } \\
\text { Plate, In } 617\end{array}$ & $\begin{array}{l}\text { Process_-single stage } \\
\text { PCHE, In } 617\end{array}$ \\
\hline Hydrogen Plant & $\begin{array}{l}\text { Hybrid thermo-chemical } \\
\text { plus electrolysis }\end{array}$ & $\begin{array}{l}\text { Initial-HTE } \\
\text { Longer term-sulfur- } \\
\text { iodine }\end{array}$ & $\begin{array}{l}\text { Initial-HTE } \\
\text { Longer term-sulfur-iodine }\end{array}$ \\
\hline Power Conversion & $\begin{array}{l}\text { Rankine; standard fossil } \\
\text { power turbine generator } \\
\text { set }\end{array}$ & $\begin{array}{l}\text { Rankine; standard fossil } \\
\text { power turbine generator } \\
\text { set }\end{array}$ & $\begin{array}{l}\text { Direct gas turbine } \\
\text { Option-direct combined } \\
\text { cycle }\end{array}$ \\
\hline
\end{tabular}

The potential licensing strategies provided by the contractor teams reflected the very preliminary nature of the NGNP design and the uncertainty regarding NRC's approach for addressing the license applications for the NGNP. The preconceptual design work, particularly that work which identified research and development and code committee work, has supported the licensing process. 
Preconceptual-level cost estimates for NGNP were developed using different methodologies that included parametric modeling, vendor quotes, actual costs, and proprietary costing databases. Reconciled cost estimates ranged from $\$ 3.8$ to $\$ 4.3$ billion based on the information and evaluations available from the preconceptual design work. The cost estimates provided by the contractor teams for the Nth of a kind commercial plant were all in the same range. All contractor teams proposed 4-unit plants with thermal power levels between 2,000 and 2,400 MWth at a cost of about $\$ 4$ billion, including owner's cost. This value was used in the economic assessments.

An NGNP Project schedule was prepared by reviewing and reconciling the preconceptual level schedules that were prepared by the contractor teams. The project schedule highlighted critical paths and identified key milestones that must be met to achieve the objective of NGNP operation in 2018. Key milestones included critical decision points for completion of design, long lead procurement initiation, submittal and receipt of critical regulatory documentation, start of construction, and licensing approval for operation. The critical paths were tied to completion of fuel qualification and completing the NRC licensing process.

Economic assessments initially established the economic viability of the HTGR technology for production of electricity and hydrogen when compared with conventional technologies and prices of natural gas. Internal rates of return in the $10 \%$ range were calculated for hydrogen and electricity production using conservative assumptions in an inflationary market. Accordingly, the results supported the continued development of NGNP and fostering the private sector application of HTGR technology.

The preconceptual design work and the associated review identified and prioritized technology selection studies (Table 2) that were required to support the final selection of NGNP operational and physical characteristics, design development studies (Table 3) that are needed to support design development of the NGNP and key development risks (Table 4) to the NGNP Project.

Reactor power level, the reactor core gas inlet and outlet temperatures, and primary system pressure are the NGNP operating conditions that have the most impact on the significance of identified risks. Temperature and pressure affect the required capabilities of materials in the nuclear heat supply system and impact the demonstration of commercialization. The metallic material risks derive from the uncertainties in qualification, availability, and the ability to fabricate large components out of materials that can reliably operate at the highest gas temperatures. Reactor fuel and core ceramics development risks stem from concerns regarding their development, qualification, and acquisition. Graphite risks come from issues pertaining to qualification, availability and fabrication processes and fabrication facilities.

Table 2. Technology selection studies.

1. Nuclear heat supply system functional and operational requirements

2. Intermediate heat exchanger and secondary heat transport loop alternatives

3. Reactor pressure vessel and intermediate heat exchanger pressure vessel alternatives

4. Reactor containment and building functions

5. Contamination control

6. Helium circulator limitations and design issues

7. White paper on pebble bed module reactor stochastic core

8. Instrumentation and control for nuclear heat supply and plant control

9. High temperature gas-cooled reactor applications

10. Hydrogen plant alternatives

11. Control room location

12. Helium supply economics 
Table 3. Design development studies.

\begin{tabular}{|ll|}
\hline 1. & Plant design requirements to support initial operations \\
2. & Design Code of Record \\
3. & Reactor Building Embedment Depth \\
4. & INL Site Selection \\
5. & $\begin{array}{l}\text { High Temperature Gas Reactor Component Test Facility F\&OR and Preconceptual Design } \\
\text { 6. }\end{array}$ \\
7. & Construction techniques \\
8. & NGNP software and hardware specifications \\
9. & In-service inspection strategy and impact \\
10. & NGNP mockup and pilot plant testing plan \\
11. & Plant-wide instrumentation and control measurement hardware \\
12. & Steam cycle concept evaluation \\
13. & Site integration (plant layout) \\
14. & Plant wide physical security plan \\
15. & NGNP waste stream identification and disposition \\
16. & INL water resource availability \\
\hline
\end{tabular}

Table 4. Key development risks.

\begin{tabular}{|c|c|}
\hline & $\begin{array}{l}\text { Qualification and acquisition of reactor fuel (e.g., qualification, fabrication, and fuel production } \\
\text { facilities) }\end{array}$ \\
\hline & Qualification of reactor core ceramics, including graphite and graphite production facilities; \\
\hline & $\begin{array}{l}\text { Qualification of metals in the high-temperature regions of the plant (e.g., in the reactor and heat } \\
\text { transfer/transport system }\end{array}$ \\
\hline & $\begin{array}{l}\text { Verification and validation of analysis methods required to support design development; American } \\
\text { Society of Mechanical Engineers (ASME) code acceptance; American Society for Testing and } \\
\text { Materials (ASTM) standards acceptance; and NRC licensing }\end{array}$ \\
\hline 5. & $\begin{array}{l}\text { Availability of materials with acceptable metallurgical and physical properties in the required sizes } \\
\text { and thicknesses and the ability to fabricate large vessels on-site using these materials }\end{array}$ \\
\hline 6 & $\begin{array}{l}\text { Availability and development of instrumentation (e.g., to monitor the fluence, high temperatures, } \\
\text { and gas flow rates in the plant) }\end{array}$ \\
\hline & Development of the hydrogen production processes and components \\
\hline & Impact of reactor operating temperature and pressure on process applications \\
\hline & Potential contamination of the product streams and meeting acceptable limits of contamination \\
\hline
\end{tabular}

While the issues pertaining to fuel, graphite, metallic materials and ceramics are being addressed by NGNP R\&D, these material risks have added uncertainty to the successful, timely and cost effective completion of the NGNP. Accordingly, the NGNP Project considered implementing a phased approach to achieving the objective operating conditions. In this approach, the plant would be operated at a lowerthan-design temperature during early operations to provide more design margin for the currently available materials. The phased operation approach would provide additional time to expand the material databases and find suitable materials for use in high-temperature environments. As will be discussed later, subsequent work concluded that there is benefit to operating the initial installations of the HTGR modules at lower temperatures. This reduced much of the key development risks summarized in Table 4 for the first-of-a-kind (FOAK) module. However, continued engineering and design development work is required to achieve the higher temperature conditions in subsequent deployments of the technology. 
The preconceptual design work also identified the need for development of testing facilities to advance the technical readiness level of critical components and systems. The capability of demonstrating large-scale components in similar conditions as they will experience in service is needed to support development of high-temperature gas thermal-hydraulic technologies (e.g., helium, helium-nitrogen, $\mathrm{CO}_{2}$ ) as applied in heat transport and heat transfer applications in HTGRs. Such applications include but are not limited to primary helium; secondary coolants; direct-cycle power conversion; intermediate, secondary and tertiary heat transfer; and demonstration of processes requiring high temperatures (e.g., hydrogen production). The initial need for such facilities would be to support the completion of the NGNP. However, the facilities would also be for use by the full range of suppliers, end-users, facilitators, government laboratories, and others in the domestic and international community supporting the development and application of HTGR technology.

The facility would provide for large scale:

- $\quad$ Testing and qualification of high temperature fluid flow systems, components, and equipment (e.g., circulators, intermediate and tertiary heat exchangers, piping, and isolation valves)

- Instrumentation and control development and qualification (e.g., reliability, calibration, response, stability, and transient response)

- $\quad \mathrm{V} \& \mathrm{~V}$ of methods/codes to support licensing and future commercial applications (e.g., thermal, hydraulic, transients, etc.)

- Heat transfer component development and fluid testing (e.g., shell and tube and compact heat exchangers, sulfuric acid decomposers)

- Materials performance (e.g., metallics and ceramics)

- Mock-up for high-temperature heat applications testing and research (e.g., prior to installation into the NGNP)

- Testing of fluid inventory and quality control systems

- Development and qualification of control room human factors

- Operations procedure development and qualification training (e.g., for NGNP and for future commercial plants)

- Operational problem/trouble shooting (e.g. for the NGNP prior to hot system repair/modifications and to support future commercial applications)

- High-temperature applications mockup engineering-scale testing and qualifications (e.g., hydrogen production, coal to liquids, steam generators for Alberta Oil Sands application, etc.)

- Maintenance and repair program and process development

- Component replacement program and process development.

The preconceptual design work provided an upper bound for the operating parameters that are believed to be achievable for the NGNP (as summarized in Table 1) and initiated the characterization of the technical risks at the extremes of these ranges. This work formed the bases for going forward in the early phase of conceptual design to expand the understanding of the risks and the alternatives to mitigate these risks in the time period left to initiate NGNP operation. Subsequently, work with the HTGR suppliers, the NGNP Industry Alliance Limited ${ }^{\mathrm{a}}$ and discussions with potential end-users and owneroperators of the HTGR plants re-defined some of the short term objectives and boundary conditions for the NGNP Project. These revisions are discussed in the following sections.

a The NGNP Industry Alliance Limited is an industry consortium formed with the assistance of the Idaho National Laboratory as directed by EPAct 2005 and the Battelle Energy Alliance contract with DOE. The Alliance members include energy endusers representing the petrochemical and petroleum industries, a nuclear owner/operator, nuclear system suppliers, a nuclear fuel and equipment vendor, and an architect-engineer/constructor. 


\section{TECHNOLOGY SELECTION STUDIES PHASE}

At the completion of the Preconceptual Design phase in FY 2007, the NGNP Project issued a Request for Expressions of Interest from prospective HTGR reactor suppliers to continue design development by performing selected further studies and proceed into conceptual design. The responses to this request that were evaluated as credible and acceptable were those from the three teams that had performed the Preconceptual Design work, with some minor changes to their teams' make-up. Blanket Master Contracts (BMC) were established with these three teams, which allowed great flexibility and response time in the awarding of identified studies and tasks.

The objective for NGNP Engineering at the initiation of the conceptual design phase in FY 2008 was to perform those studies that would identify and/or refine functional, performance, and operational requirements that respond to potential owner/operator and end-user needs. These studies had been identified in the PCDR as Technology Selection Studies (see Table 2). The studies with the highest priorities were initiated and integrated as shown in Figure 1.

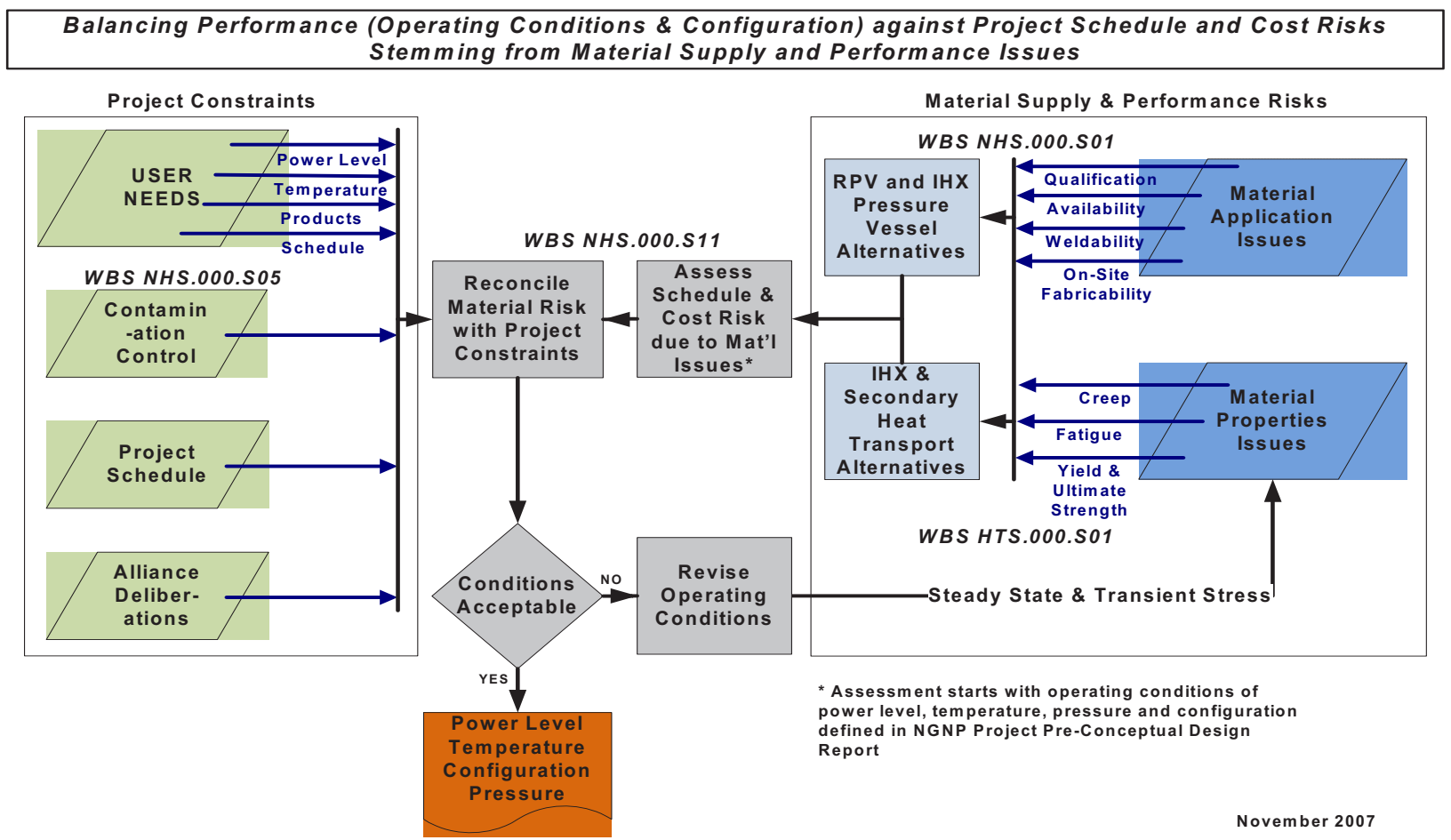

Figure 1. FY 2008 conceptual design technical selection studies integration.

These studies, combined with others related to reactor building functions, power conversion system alternatives, hydrogen plant alternatives, use of composite materials, and reactor parametric studies, led to reassessments of technology/design selections for fundamental concepts such as reactor design, power rating, reactor outlet temperature, and fundamental loop and cycle configuration.

Concurrent with these studies, the associated DDNs, Technology Readiness Levels (TRL), ${ }^{7}$ Technology Development Roadmaps (TDRM), ${ }^{8}$ Risk Register, and risk management system ${ }^{9}$ were developed and tracked for the $950^{\circ} \mathrm{C}$ reactor outlet temperature designs.

Progressively more detailed studies were performed where warranted, either by the conclusions of previous studies or by integrating the information developed through the DOE Generation IV Reactor Materials project managed by the American Society of Mechanical Engineers (ASME) ST,LLC. The 
design development studies that were identified in the PCDR (see Table 3) were not initiated, as they were very site-specific in nature and would depend on some narrowing of potential site selection.

The "User Needs" study ${ }^{10}$ in particular led to reconsidering the risks of pursuing the higher reactor outlet temperature $\left(950^{\circ} \mathrm{C}\right)$ and its associated development needs against the potential marketability of an HTGR at a lower reactor outlet temperature. Refinement of the information obtained from potential end users revealed that some industrial process applications in addition to hydrogen production could potentially be met with lower reactor outlet temperature energy in the range of 700 to $800^{\circ} \mathrm{C}$, rather than 900 to $950^{\circ} \mathrm{C}$. The NGNP Project subsequently broadened the engagement of the industrial sector to support evaluation of the potential market for the NGNP. 


\section{END-USER INPUT TO DEFINE SCOPE AND REQUIREMENTS}

The industrial sector, particularly those entities who require high-temperature process heat in significant quantities, is the major market segment targeted for deployment of technology. The high temperature capability of this technology makes it a viable non-greenhouse-gas-emitting energy supply for a wide range of industrial processes as a substitute for the use of fossil fuels. Such applications include the supply of steam, electricity and high-temperature gas in co-generation applications, recovery of nontraditional hydrocarbons from oil sands and oil shale, supply of hydrogen and oxygen for the production of ammonia, conversion of coal to transportation fuels, and petro-chemical process feedstock. As the ultimate end-users of the technology, input from the industrial sector has been and continues to be a key element in developing the functional requirements for commercializing this technology. These functional requirements inform the configuration and plant design, licensing, construction, testing and operational requirements developed by the potential plant operators, (e.g., current nuclear plant owner/operators) and the HTGR suppliers.

The NGNP Project has engaged with potential end users to identify and characterize the requirements for HTGR application and to establish the interest in the industrial sector for application of the HTGR technology. The NGNP Project also formed the Senior Advisory Group (SAG), made up of leaders representing reactor suppliers, end-users, and owner operators. The SAG has met three times over the course of the NGNP Project and provided recommendations on the configurations and operating conditions for the NGNP plant to meet best industry needs. The NGNP Project has also contracted and performed internal evaluations ${ }^{10,11}$ to identify the industrial uses of energy, quantities of energy required for candidate industrial processes, and energy characteristics such as type, temperature, and pressure. Finally, the NGNP Project has also interfaced with the NGNP Industry Alliance that is compromised of representatives of the HTGR Suppliers, an owner/operator of nuclear plants and several end users to further define the needed characteristics of the HTGR technology. The culmination of all of this effort leads to the following conclusions:

1. The industry judges the technology has technical merit, but to be effective it should be available for commercial application no later than the mid-2020s.

2. Multiple modules of nuclear heat supply systems will be required to satisfy the total energy needs and availability requirements of the processes.

3. To confirm the technical, licensing, and economic viability of the technology, the initial application of the technology should be a FOAK module with planned flexibility to become a multi-module commercial application rather than remaining solely as a demonstration plant

4. Reactor outlet temperatures in the 700 to $800^{\circ} \mathrm{C}$ range would be sufficient to satisfy the initial temperature needs of industry, but pursuit of higher reactor outlet temperatures should be continued for future higher temperature applications.

5. Steam, electricity, and hot gas are the principal forms of energy required to satisfy the current needs.

6. Along with supplying steam, electricity, and hot gas, an economic supply of hydrogen from the HTGR would permit the upgrade of current industrial processes to increase efficiency and reduce greenhouse gas emissions (e.g., petrochemical processes, conversion of coal to synthetic fuels, fertilizer manufacturing).

\subsection{Continuing Flexibility and Desire to Achieve Higher Operating Limits}

The NGNP designs under consideration at this time do address these six conclusions described above. While these conclusions result in a best near-term deployment pathway by balancing technical risk and 
market needs, there is still a desire to provide flexibility in plant configuration and operating conditions in order to meet a wider range of the energy supply needs of the industrial sector. The plant should be configurable, for example, to supply only steam and electricity in an industrial plant co-generation application or in support of Bitumen extraction in the Canadian oil sands. The plant should also be configurable to supply high temperature gas to an industrial process such as a petro-chemical cracker or for the production of hydrogen and oxygen for use in refining, ammonia production or coal conversion to fuels and feedstock. The near-term application of the HTGR technology for these purposes is being developed for a reactor outlet temperature in the 700 to $800^{\circ} \mathrm{C}$ range. This temperature allows the reactor to supply steam at temperatures up to $593^{\circ} \mathrm{C}$ or high-temperature secondary circuit gas at a temperature of 700 to $725^{\circ} \mathrm{C} ; 25$ to $50^{\circ} \mathrm{C}$ can be lost when process heat is transferred to the industrial application.

This steam temperature range is sufficient for most co-generation applications. However, the high temperature gas temperature range is at the lower level usable for most industrial applications. The use of this temperature for hydrogen production using high temperature steam electrolysis (see section below) reduces the efficiency of the process by about 6-10\%. It was concluded, however, that because this reduced temperature range provides more margin in the operation of the fuel and graphite, and permits use of materials already covered by or requiring less-complex extensions to the ASME Code, the technical risk in meeting an initial startup date in the mid-2020s is reduced. Accordingly, since the lower temperature range would also meet a significant fraction of the energy needs of industrial processes, this lowering of the initial NGNP objectives on reactor outlet temperature is justified.

While lowering the outlet temperature facilitates technology selection and decreases the scheduling risks, NGNP Project HTGR integration studies show that higher outlet temperatures increase the range of applications and improve the efficiency of applying the technology to industrial processes. ${ }^{11}$ This integration study included detailed development of mass and energy balances, including process inputs, heat requirements, products generated, and carbon dioxide emissions. The results showed that, for some industrial applications, HTGR integration would improve yields and reduce carbon dioxide emissions by 54 to $100 \%$. This study also included evaluation of the economics of these applications. These evaluations concluded that the HTGR integrated industrial processes were competitive with conventional industrial processes (depending on the costs and financial parameter assumptions used for analysis) and the price of natural gas in cases where natural gas is the primary source of energy in the conventional process.

Realization of the full benefits of integrating the HTGR technology with some of the industrial processes requires economic supply of hydrogen to the process, (e.g., coal to gasoline via the methanol to gasoline process, coal to diesel conversion, production of ammonia directly with nitrogen). Prior to FY 2010, hydrogen production research and development was funded through the DOE Nuclear Hydrogen Initiative (NHI). Up through FY 2008, hydrogen production technologies under development and being considered by NHI were the sulfur-iodine process, the hybrid-sulfur process, and hightemperature steam electrolysis (HTSE). ${ }^{12}$ These were the processes included in the plant designs developed in the preconceptual design work in FY 2007. During FY 2009, the NGNP Hydrogen Technology Down-Selection Independent Review Team recommended the selection of HTSE as the hydrogen production process for further development. ${ }^{13}$ When the NHI Initiative ended at the end of FY 2009, HTSE for hydrogen production was incorporated into NGNP research and development project scope. 


\section{UPDATED REFERENCE CONFIGURATIONS}

Following the aforementioned engagement of potential end-users and the concurrence of the SAG and DOE, NGNP Engineering adopted a reactor outlet temperature range of 750 to $800^{\circ} \mathrm{C}$ range as a target requirement and used this lower temperature range as a basis for studies performed in FY 2009. Several studies were performed related to the impact of this lower temperature and allowance for steam generators in the primary coolant loop. The results of these studies can be summarized as follows:

- The reactor pressure vessel and steam generator or heat exchanger pressure vessels may be fabricated from standard light water reactor (LWR) metals, such as SA 508/533.

- The recommended power conversion system is a Rankin cycle steam plant using standard LWR steam plant components where possible.

- Helium circulators up to $6 \mathrm{MWe}$ (about $8,000 \mathrm{hp}$ ) in size and $350^{\circ} \mathrm{C}$ (generally corresponding to an NGNP reactor outlet temperature of $750^{\circ} \mathrm{C}$ ) are within current circulator capabilities. Thus, if the end user needs supported multiple modules of smaller power level HTGRs such that primary circulator needs were no greater than $6 \mathrm{MWe}$, the circulator development was fairly mature.

Concurrent with these new studies, the reference configurations were updated by the three design supplier teams to reflect the 750 to $800^{\circ} \mathrm{C}$ range for reactor outlet temperature designs and the associated DDNs, TRL, TDRM,${ }^{14}$ Risk Register, and risk management system were revised accordingly. At this time, the reference configurations for the design supplier teams recommending the prismatic block reactors included steam generators in the primary circuit instead of intermediate heat exchanger (IHX). The reference configuration for the pebble bed reactor still included an IHX, but had been revised to only use a single IHX, as opposed to the two IHXs in series that had been proposed in the preconceptual design. The System Requirements Manual that had been maintained by NGNP Engineering as an informational document for initiating conceptual design was also updated to reflect the lowered reactor outlet temperature and migrated to a relational database to allow more efficient updating and sorting of requirements. These documents that define the updated reference configurations and associated DDNs, TDRMs, and TRLs are available to inform any continued design development.

In a meeting of the SAG in March 2009, the pebble bed technology team led by Westinghouse/PBMR Pty Ltd. advised the participants that they intended to revise the pebble bed core design from the annular configuration originally proposed for NGNP to a cylindrical configuration at a lower power rating in the range of 200 to $250 \mathrm{MWth}$ and that their reference configuration would then include a steam generator in the primary circuit and operation with a reactor outlet temperature in the range 700 to $750^{\circ} \mathrm{C}$. Although this configuration formed the basis of the pebble bed reactor design team's response to the DOE's Funding Opportunity Announcement (FOA) $)^{b}$ for Phase 1, this configuration is not documented in NGNP Project records. More recently the end-users in the NGNP Industry Alliance consider that the the first generation offering of the HTGR needs to also provide hot process gas (e.g., helium) at the highest practical temperature for existing applications that cannot be reasonably modified to use the cogeneated electricity and steam.

b The Financial Assistance FOA, DE-FOA-0000149, was the procurement mechanism used to solicit bids and eventually make award(s) to prospective reactors supplier(s) who desired to complete a conceptual design of the NGNP under a costsharing agreement with the DOE. At the time of this writing, only General Atomics was awarded a contract under this FOA, and their conceptual design is the only one expected to be completed for NGNP under this FOA. 


\section{PROCESS HEAT APPLICATION INTEGRATION EFFORT}

Several potential applications have been identified and evaluated that appear to have large, viable and long-term markets for heat generated by an HTGR as discussed in the INL white paper High Temperature Gas-cooled Reactor Projected Markets and Scoping Economics. ${ }^{15}$ Based on this initial study of applications, the NGNP Project selected five processes that utilize HTGR-generated heat, electricity, and hydrogen to analyze in greater detail to determine whether it would be technically and economically practical to integrate one or more HTGRs into conventional industrial production processes. The five processes selected were: synthetic gasoline, synthetic diesel production from coal and natural gas, ammonia (and ammonia derivatives) production, recovery of bitumen via the HTGR-integrated steam assisted gravity drainage (SAGD) process, and production of substitute natural gas from coal.

For each of these processes, detailed chemical process models were developed with the Aspen Plus ${ }^{\circledR}$ modeling package. The process models for the HTGR-integrated cases assumed that one or more 600-MWth HTGRs (based on the preconceptual configurations) were physically located near the conventional industrial-process plant. The results of the process models were documented in the report Integration of High Temperature Gas-Cooled Reactors into Industrial Process Applications. ${ }^{16}$

The process models were independently reviewed by external reviewers who have significant experience in developing and applying similar models for petrochemical industries. The reviewers participated with the NGNP Project to resolve comments and concluded that the models were acceptable subject to recommended modifications. Some of the key modeling parameters, such as operating temperatures and pressures for ammonia and ammonia derivatives production were validated during visits to operating plants. As a result, the process models are reasonably close to current industrial practice.

An economic analysis was developed for each of the conventional and HTGR-integrated process models to assess the economic viability of integrating HTGR technology into the selected conventional industrial processes. The economic models included capital and operating costs and revenues, in a discounted cash flow analysis that adjusted product revenues to achieve a required internal rate of return. Capital cost estimates for the processes supplied by the HTGR meet the requirements established by the Association for Advancement of Cost Engineering International Class 5 (with an expected accuracy range of -50 to $+100 \%$ ). Manufacturing costs are the sum of: direct production costs for raw materials, utilities, operating labor, and maintenance; and indirect costs including plant overhead, insurance, and taxes. The capital and operating cost estimates for the HTGR are based on reconciliation of costs developed in the FY 2007 pre-conceptual design work and selected engineering studies completed in FY 2008 and FY 2009.

The economic results show that HTGR-integrated processes would offer more predictable and stable energy prices than the conventional processes because their operating costs are more predictable and stable and because they are not significantly affected by fluctuations in fossil fuel prices. When these fossil fuel prices are at the higher end of the historical as well as postulated price ranges, conventional processes face a significant challenge to remain profitable, a challenge that increases if efforts are made to offset the cost of carbon emissions using a carbon tax or equivalent policy. Though nuclear fuel prices also fluctuate, the fuel cost is a much smaller fraction of the operating costs for an HTGR plant compared to the fossil-fuel-cost-to-operating-cost fraction for a conventional plant.

The most economically viable HTGR-integrated opportunities (from those evaluated to date) appear to be processes that produce synthetic gasoline, synthetic diesel, and ammonia derivatives. The analyses also indicated that integrating HTGRs with processes that utilize coal as a feedstock are not as viable as integrating with those that utilized natural gas. However, coal-based process integration would be competitive if the HTGR capital investment is reduced or if more HTGR modules are located within a single plant. As HTGR technology matures and outlet temperatures increase, integrating HTGR 
technology into other industrial processes, including those that utilize coal, will become increasingly favorable.

If the elimination or significant reduction of GHG emissions supersedes economic considerations or a carbon tax is imposed, the analyses suggest that all of the evaluated HTGR-integrated processes would be competitive.

Two significant conclusions about HTGR-integrated processes can be made based on evaluation of the engineering analyses of HTGR-integrated process applications:

- The evaluated HTGR-integrated industrial processes, including electricity generation, and $\mathrm{H}_{2}$ production, have a significantly lower carbon footprint than conventional processes

- Some of the evaluated HTGR-integrated industrial processes appear to be similarly economically viable as compared to conventional processes, even without a carbon tax or a substantial increase in natural gas prices. 


\section{CODES, STANDARDS, AND DESIGN RULES DEVELOPMENT}

The licensing and operation of the NGNP will require the advancement and completion of a number of National Standards and Consensus Codes (Table 5). The ASME, ANS, and American Society for Testing and Materials International (ASTM) have all been supportive of the NGNP and have been involved with the standards and codes advancement activities. The ASME has developed a path forward for many of the code related issues in their Roadmap for the Development of ASME Code Rules for High Temperature Gas Reactors that is currently in draft form (Revision 8). This roadmap will be used to track the ASME Code Cases activities needed for codification of materials and material joining techniques at the elevated temperatures of the HTGR.

Development of the ASME Code Cases will require substantial research and technology development and the development of ASTM specifications. The general approach regarding materials is governed by the concept that any basic research that will support generation of new or revised ASTM specifications or standards will be managed by the NGNP R\&D organization. Generation or revision of higher-level National Standards and Codes, such as the ASME Boiler \& Pressure Vessel (B\&PV) Code will be managed by NGNP Engineering. The NGNP team has positioned personnel in several key positions to advance codes and standards development in collaboration with national standard and consensus code organizations. 
Table 5. Advancement of codes, standards and rules for the operation of high temperature gas-cooled reactors.

\begin{tabular}{|c|c|c|}
\hline Code/Standard & Status and Relevance & Project Involvement \\
\hline $\begin{array}{l}\text { ANSI/ANS - 53.1, } \\
\text { Nuclear Safety Criteria } \\
\text { and Safety Design } \\
\text { Process for Modular } \\
\text { Helium-Cooled Reactor } \\
\text { Plants. }\end{array}$ & $\begin{array}{l}\text { This standard is in development and has been through a } \\
\text { balloted review once. A revised draft completed working } \\
\text { group internal review and was provided to the ANS' Nuclear } \\
\text { Facility Standards Committee for final review and comment } \\
\text { prior to the June } 2010 \text { ANS summer meeting. Currently } \\
\text { awaiting final comments before submittal for ballot. Needed } \\
\text { for development of other code rules. }\end{array}$ & $\begin{array}{l}\text { An engineering staff member was formally accepted in } \\
2009 \text { onto the ANS-28 Subcommittee of the American } \\
\text { Nuclear Society and is a member of the ANS- } 53.1 \\
\text { Working Group engaged in issuing the standard, which } \\
\text { is anticipated to complete in } 2010 \text {. }\end{array}$ \\
\hline $\begin{array}{l}\text { ASME PRA Standard, } \\
\text { Standard for Probabilistic } \\
\text { Risk Assessment for } \\
\text { Advanced Non-LWR } \\
\text { Nuclear Power Plant } \\
\text { Applications. }\end{array}$ & $\begin{array}{l}\text { This standard is in development and has been through a } \\
\text { balloted review once. Review comments need to be addressed } \\
\text { and a revised draft submitted. Needed for development of } \\
\text { other code-rules. }\end{array}$ & $\begin{array}{l}\text { The NGNP Project has subcontracted with the ASME's } \\
\text { Committee for Nuclear Risk Management Non-Light } \\
\text { Water Reactor Plants Working Group chair to ensure } \\
\text { this standard is completed after progress was halted } \\
\text { during FY 2009. The INL lead for Risk, Reliability \& } \\
\text { NRC Programs is also a member of the Working Group } \\
\text { that is developing this new PRA standard. }\end{array}$ \\
\hline $\begin{array}{l}\text { ASME's Roadmap for the } \\
\text { Development of ASME } \\
\text { Code Rules for High } \\
\text { Temperature Gas } \\
\text { Reactors. }\end{array}$ & $\begin{array}{l}\text { This is not actually a standard, but is a roadmap/plan of code- } \\
\text { rule activities needed to support HTGR development. Many } \\
\text { roadmap tasks are included within the various ASME B\&PV } \\
\text { Code updates listed below. Other tasks are being addressed } \\
\text { by ASME Standards Technology, LLC organization, which is } \\
\text { currently managing } 16 \text { tasks related to the NGNP Project, of } \\
\text { which } 11 \text { are completed. The ASME ST,LLC will publish } \\
\text { this roadmap in } 2010 \text { as an ASME publication. }\end{array}$ & $\begin{array}{l}\text { The NGNP Project is represented by two Technical } \\
\text { Representatives on the ASME ST-LLC Steering } \\
\text { Committee. The representatives' function is to ensure } \\
\text { that the work sponsored through the ASME ST-LLC } \\
\text { gives highest priority to NGNP Project needs. The two } \\
\text { representatives of the NGNP Project and also other } \\
\text { project staff supporting the ASME B\&PV Code, } \\
\text { Section III working groups will also provide review } \\
\text { and comment regarding the completion of the ASME } \\
\text { ST-LLC tasks. Note also that the NGNP Project will } \\
\text { directly perform or lead much of the R\&D and other } \\
\text { efforts to develop associated ASTM Specifications for } \\
\text { materials and joining methods of interest. }\end{array}$ \\
\hline ASME B\&PV Code & $\begin{array}{l}\text { Various updates applicable to both } 750 \text { and } 950^{\circ} \mathrm{C} \text { reactor } \\
\text { outlet temperatures have been initiated. These are needed to } \\
\text { qualify material and design rules for nuclear construction. } \\
\text { Section II - Update needed to account for new materials. } \\
\text { Order and priority is dependent on reactor outlet temperature } \\
\text { and design configuration \& material selections. }\end{array}$ & $\begin{array}{l}\text { The NGNP Project is represented by staff members } \\
\text { from the INL and/or Oak Ridge National Laboratory on } \\
\text { the following committees and groups: } \\
\text { - Subgroup on High Temperature Reactors (Section } \\
\text { III) }\end{array}$ \\
\hline
\end{tabular}




\begin{tabular}{|c|c|c|}
\hline Code/Standard & Status and Relevance & Project Involvement \\
\hline & $\begin{array}{l}\text { Section III - Updates needed for existing Code Cases. The } \\
\text { order and priority of work is highly dependent on the } \\
\text { selection of reactor outlet temperature and design } \\
\text { configuration \& material selections. Efforts for the following } \\
\text { materials have all been discussed: } 308,316,617,800 \mathrm{H}, \mathrm{Gr} 91 \\
\text { (9Cr-1Mo), } 2 \text { 1/4Cr-1Mo, Hastelloy X, Hastelloy XR. } \\
\text { Section III, Subsection NH - need to extend and simplify } \\
\text { Code rules to anticipated temperatures. } \\
\text { Section III, Division } 5 \text { - will consolidate near-term needs for } \\
\text { HTGRs from Subsection NH such that issues concerning } \\
\text { other elevated temperature service related issues, such as } \\
\text { those for liquid metal reactors, don't prevent rapid progress } \\
\text { for NGNP needs. } \\
\text { Section III, Graphite Code Cases (general requirements and } \\
\text { design rules) } \\
\text { Section V - address new NDE techniques applicable to } \\
\text { VHTRs. } \\
\text { Section XI, Division } 2 \text { - new part anticipated for rules for in- } \\
\text { service inspection, maintenance, and repair of HTGRs. A } \\
\text { draft has been written. }\end{array}$ & $\begin{array}{l}\text { - Working Group on Nuclear High Temperature Gas } \\
\text { Cooled Reactors (Section III) - } \\
\text { - An INL staff member was recently named the Code } \\
\text { Committee Project Manager for the development of } \\
\text { Division V, Part 1, High Temperature Gas } \\
\text { Reactors, and prepared the draft of this new } \\
\text { document } \\
\text { - A Project representative on this Working Group } \\
\text { was recently nominated as the Working Group } \\
\text { chair by the head of ASME Section III. } \\
\text { - Subgroup on Graphite Core Components (Section } \\
\text { III) } \\
\text { - Subgroup on Elevated Temperature Design } \\
\text { (Section III) } \\
\text { Special Working Group on HTGRs (Section XI) }\end{array}$ \\
\hline $\begin{array}{l}\text { ASTM/ASME efforts } \\
\text { regarding } \\
\text { Composite/Ceramic } \\
\text { materials, for example C- } \\
\text { C }\end{array}$ & $\begin{array}{l}\text { Composite materials are primarily a consideration for the } \\
950^{\circ} \mathrm{C} \text { reactor outlet temperature, but they may have } \\
\text { applicability at } 750^{\circ} \mathrm{C} \text { in such areas as inner, outer, and upper } \\
\text { Core Restraints. }\end{array}$ & $\begin{array}{l}\text { No significant R\&D or code efforts have been initiated } \\
\text { regarding composite/ceramic materials. This should be } \\
\text { initiated early in Phase } 2 \text { for those needs identified in } \\
\text { Phase } 1 \text { configurations. }\end{array}$ \\
\hline $\begin{array}{l}\text { ASME Operations \& } \\
\text { Maintenance (O\&M) } \\
\text { Standard }\end{array}$ & $\begin{array}{l}\text { Anticipated to be a self-contained book supporting Section } \\
\text { XI, Division } 2 \text {. Applicable to both } 750 \text { and } 950^{\circ} \mathrm{C} \text { reactor } \\
\text { outlet temperatures. }\end{array}$ & $\begin{array}{l}\text { The NGNP Project is looking to develop a more direct } \\
\text { role with the O\&M Subgroup to aid in developing the } \\
\text { O\&M standard }\end{array}$ \\
\hline $\begin{array}{l}\text { International Atomic } \\
\text { Energy Agency (IAEA), } \\
\text { Department of Safeguards }\end{array}$ & $\begin{array}{l}\text { International standards related to Safeguards and Security for } \\
\text { LWRs must be adapted for HTGRs. }\end{array}$ & $\begin{array}{l}\text { A Project staff member is the INL Program Lead for } \\
\text { Nuclear Energy Nonproliferation, Safeguards and } \\
\text { Security and is engaged with the IAEA. }\end{array}$ \\
\hline
\end{tabular}


INL/EXT-10-19261

\section{REFERENCES}

1. Energy Policy Act of 2005, Public Law No. 109-58, U.S. Congress, August 8, 2005.

2. Idaho National Laboratory, Design Features and Technology Uncertainties for the Next Generation Nuclear Plant, Independent Technical Review Group, INL/EXT-04-01816, June 30, 2004.

3. Westinghouse Electric Company, LLC, NGNP and Hydrogen Production Preconceptual Design Report: Executive Summary Report, NGNP-ESR-RPT-001, Rev. 0, May 2007, with subsections.

4. AREVA NP Inc., NGNP with Hydrogen Production Preconceptual Design Studies Report, 129051191-001, June 2007.

5. General Atomics, Preconceptual Engineering Services for the Next Generation Nuclear Plant (NGNP) with Hydrogen Production: Executive Summary Report - NGNP and Hydrogen Production Preconceptual Design Studies Report, PC-000544, Rev. 0, July 10, 2007.

6. Idaho National Laboratory, Next Generation Nuclear Plant Pre-Conceptual Design Report, INL/EXT-07-12967, Rev. 1, November 2007.

7. Idaho National Laboratory, NGNP - Creating Validated TRL and TDRMs for Critical Systems, Subsystems, and Components, INL/EXT-08-14842, September 2008.

8. Idaho National Laboratory, Next Generation Nuclear Plant Project Technology Development Roadmaps: The Technical Path Forward, INL/EXT-08-15148, January 2009.

9. Idaho National Laboratory, NGNP Risk Management through Assessing Technology Readiness, INL/EXT-10-19197, Rev. 0, August 2010.

10. MPR-3181, Survey of HTGR Process Energy Applications, Rev. 0, May 2008.

11. Idaho National Laboratory, Integration of High Temperature Gas-Cooled Reactors into Industrial Process Applications, INL/EXT-09-16942, Rev. 2, May 2010.

12. Idaho National Laboratory, Maintaining a Technology-Neutral Approach to Hydrogen Production Process Development through Conceptual Design of the Next Generation Nuclear Plant, INL/EXT08-14193, May 2008.

13. Dominion Engineering, Inc., NGNP Hydrogen Technology Down-Selection: Results of the Independent Review Team (IRT) Evaluation, R-6917-00-01, Rev. 0, July 31, 2009.

14. Idaho National Laboratory, Next Generation Nuclear Plant Project Technology Development Roadmaps: The Technical Path Forward for $750-800^{\circ} \mathrm{C}$ Reactor Outlet Temperature, INL/EXT-0916598, August 2009.

15. Idaho National Laboratory, High Temperature Gas-cooled Reactor Projected Markets and Scoping Economics, INL/EXT-10-19037, August 2010.

16. Idaho National Laboratory, Integration of High Temperature Gas-Cooled Reactors into Industrial Process Applications, INL/EXT-09-16942, Rev. 1, February 2010. 